\title{
Tracing Lithosphere Melt Compositions using Polymict Peridotites
}

\author{
Lisa Morfi $^{1}$, Ben Harte ${ }^{1}$, John J. Gurney ${ }^{2}$ \\ 1) School of GeoSciences, University of Edinburgh, Scotland, Great Britain, morfi_lisa@hotmail.com \\ 1) School of GeoSciences, University of Edinburgh, Edinburgh, Scotland, Great Britain, ben.harte@ed.ac.uk \\ 2) Geological Sciences, University of Cape Town, Rondebosch, South Africa, john.gurney@minserv.co.za
}

\section{Introduction to Polymict Peridotites and related rocks}

Polymict peridotites are an exceptional suite of mantle xenoliths recovered from kimberlites in the Kimberley area of South Africa. The xenoliths have breccia-like characteristics and contain rock and mineral fragments (collectively referred to as clasts) usually consisting dominantly of olivine and orthopyroxene. The clasts are embedded in matrix rich in phlogopite together with other silicates, ilmenite, rutile and sulphides. Polymict xenoliths were first described by Lawless et al. (1979, Proc. Int. Kimb. Conf, 2), who considered the matrix to represent a metasomatic fluid. In this submission we will show that this fluid appears to be in equilibrium with silicate and oxide minerals, and was most probably a melt showing similarities to other mantle metasomatic melts (e.g. Harte et al., 1993, Phil. Trans. R. Soc. Lond. A)).

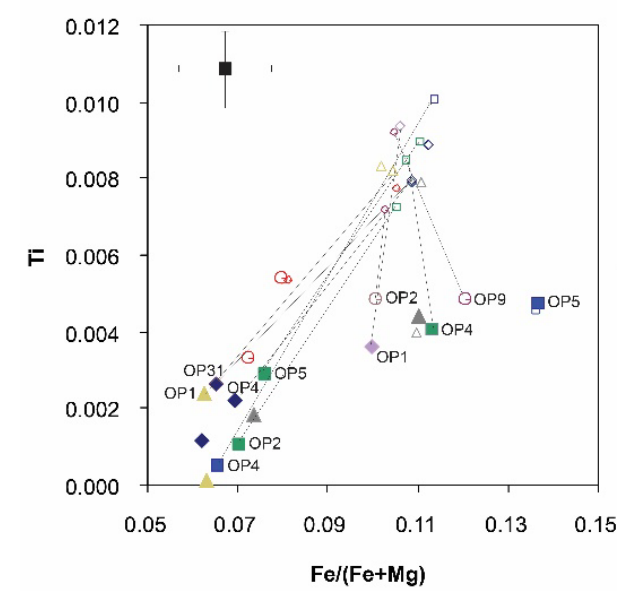

Figure 1.: Compositional variations in cations between cores (solid symbols) and rims (open symbols) of orthopyroxene in Polymict Peridotites; tie-lines connect cores and rims of the same grain.

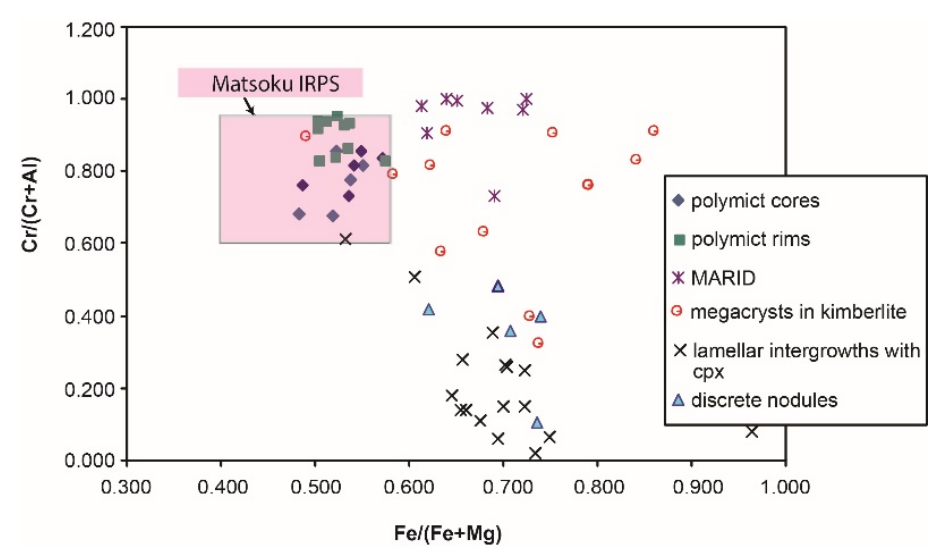

Figure 2: Ilmenite compositions, $\mathrm{Cr} /(\mathrm{Cr}+\mathrm{Al})$ vs $\mathrm{Fe} /(\mathrm{Fe}+\mathrm{Mg})$, for Polymict Peridotites and other ilmenite suites. The Matsoku box encompasses ilmenite compositions for Matsoku suite xenoliths.

A detailed electron microprobe and ion microprobe (SIMS) study has been made of eleven polymict xenoliths. The clastic grains are very dominantly minerals related to peridotitic and megacrystic xenolith/xenocryst suites, though a rare eclogite fragment has been identified. The clasts have variable compositions, and many show rims with chemical zoning in major-minor-trace elements. These rims sometimes show complex and oscillatory zoning, but overall the rim compositions of phlogopite, orthopyroxene and garnet show a convergence towards the compositions of these phases in the matrix in each xenolith, and the matrix compositions are believed to indicate the nature of metasomatic infiltrating melt. In one polymict xenolith (BD2394), showing a substantial pool of matrix with orthopyroxene +phlogopite+garnet+ilmenite, there is a close consistency of mineral compositions, and similar compositions are found in the matrix of other polymict xenoliths. In addition these matrix compositions are also closely similar to those found in xenoliths showing intrusive veins and sheets of Matsoku type with the IRPS (ilmenite-rutile-phlopite sulphide) metasomatic suite Harte et al. 1993). These features suggest the possibility that the rim compositions and matrix compositionsof the polymict peridotites crystallised from melts similar in composition to those forming veins and sheets in the Matsoku xenoliths. Furthermore, the IRPS minerals in the Matsoku rocks appear to be in equilibrium 
with abundant clinopyroxene, garnet, orthopyroxene and olivine (Harte et al., 1987, 1993). The abundance of all these minerals occurring in the Matsoku xenoliths in apparent textural and compositional equilibrium provides an excellent opportunity for determining a wide set of mineral compositions in equilibrium with melt within the lithosphere. Simultaneously, it provides an opportunity for estimating the composition of actual melts involved with the formation of the polymict peridotites and the Matsoku type metasomatic rocks.

\section{Determination of Mineral/Mineral and Melt/Mineral Partition Coefficients.}

A set of five xenoliths belonging to the Matsoku IRPS were selected for detailed electron microprobe and ion microprobe analysis at the NERC/Edinburgh University Ion Microprobe Facility (see Burgess and Harte, 2004, for details of analytical techniques). Emphasis was placed upon the Matsoku rocks, rather than the Polymict xenoliths, because of their closer approach to widespread textural and chemical equilibrium. These data were then used to determine melt compositions in the following steps:

a) Trace element compositions were analysed for all phases (clinopyroxene, garnet, orthopyroxene, phlogopite and olivine) in the five selected xenoliths.

b) The partition coefficients of trace elements between different phases were calculated from the analysed mineral compositions (e.g. clinopyroxene ppm/garnet ppm).

c) The average experimental data determined for trace element partitioning between clinopyroxenes and melts by Grutzeck et al. (1974), and Hart and Dunn (1993) were adopted, and the compositions of melts in equilibrium with the clinopyroxene compositions of (a) above calculated.

d) Using the mineral/mineral partition coefficients of (b) in conjunction with the melt compositions determined in (c), a complete of set of melt/mineral partition coefficients were obtained for all phases (clinopyroxene, garnet, orthopyroxene, phlogopite and olivine).

e) With an anaysis of any one phase, the melt composition in equilibrium with that phase could be calculated. Applying this to several phases in one xenolith, and examining the similatiry of melt compositions obtained, also a gave a test of the extent to which equilibrium existed between the phases and the validity of the partiton coefficients used.

As an example, Figure 4 shows the cpx/garnet partition coefficients

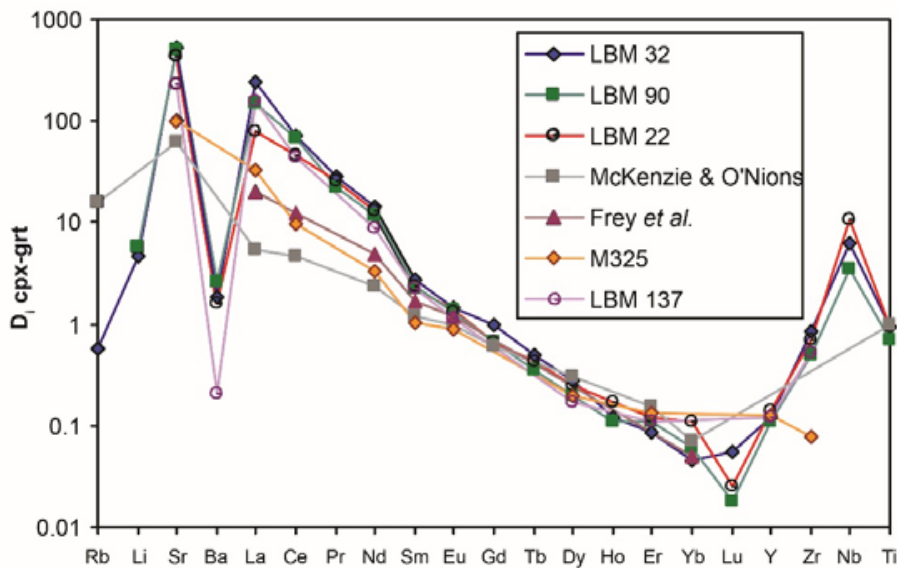

Figure 4: Clinopyroxene-garnet partition coefficents. The LBM data are for Matsoku xenoliths; The data from McKenzie and O’Nions 1991) and Frey et al. (1978) are calculated from their $\mathrm{cpx} / \mathrm{melt}$ and garnet/melt partition coefficients.

calculated for four Matsoku xenolioths, and the same partiton coefficients implied by cpx/melt and garnet/melt data in the publications of McKenzie and O'Nions (1991), and Frey et al. (1978). The consistency of the Matsoku data is apparent. The difference between the Matsoku data and McKenzie and O'Nions data may be attributed to the adoption of data from Shimizu and Kushiro (1975) and the over-estimation of LILE data for garnets at that time (see also Burgess and Harte, 2004).

The newly derived sets of melt/mineral trace element partition coefficents derived from steps (a) to (e) above, have then been used to determine the compositions of the melts associated with the range of polymict xenoliths and IRPS suite xenoliths of Matsoku. Considerable similarities of melt compositions are found using all melt mineral partition coefficients for each xenolith, and between both the Polymict and Matsoku sets of xenoliths. 
An extract of this data is shown in Figure 5 using average melt compositions determined using the calculated melt/garnet partition coefficients for the average matrix garnet in polymict BD2394 and Matsoku garnets. As may be seen (Figure 5) the average melt compositions for the BD2394 polymict and the Matsoku suite show considerable similarities to one another. They are also very similar to compositions shown by Type II kimberlites (Tainton 1992). Thus close similarities of melt composition are shown for all these rocks.

Harte et al. (1993) and Burgess and Harte (2004) have previously suggested that the melts responsible for diverse metasomatic phenomena in Matsoku and Jagersfontein mantle xenoliths, may have been derived by differentiation from the melts giving rise to megacryst suite minerals, which also show similarities to low-percentage melts of the MORB source (Figure 5). In Figure 5, the compositions of melts based on garnet megacrysts and the MORB source show considerable similarities; they also similarities to the BD2394Polymict/Matsoku/Type II kimberlite melts for the heavy REE and Y-Zr-Nb elements. For the LREE and LILE elements, the Polymict/Matsoku/Type II kimberlite compositions show gradually increasing concentrations compared to those seen in the Megacryst and MORB-source melt compositions (Figure 5). This trend to increasing LREE and LILE might be explained by garnet fractionation from Megacryst and MORBsource melts as the percolate upwards through the lithosphere, in a manner similar to that suggested for Jagersfontein percolating melts (Burgess and Harte, 2004).

\section{References}

Burgess, S.R. \& Harte, B. (submitted) Tracing lithosphere evolution through the analysis of heterogeneous G9/G10 garnet in peridotite xenoliths, II: REE chemistry. J Pet 45:609-634

Frey, F.E., Green, D.H., Roy, S.D. (1978) Integrated models of basalt petrogenesis: J Pet 19: 463-513.

Grutzeck M, Kridelbough ., Weill, D. (1974) The distribution of Sr and REE between diopside and silicate liquid. Geophys Res Lett 1: 273-275.

Hart SR, Dunn T (1993) Experimental cpx/melt partitioning of 24 trace elements. Contrib Min Pet 113:1-18

Harte B. Gurney JJ (1975) Ore mineral and phlogopite mineralisation within ultramafic nodules from the Matsoku kimberlite pipe, Lesotho. Yrbook Carn Inst Wash 74: 528-536

Harte B, Hunter RH, Kinny PD (1993) Melt geometry, movement and crystallisation, in relation to mantle dykes, veins and metasomatism. Phil Trans Roy Soc Lond A 342:1-21.

Harte, B., Winterburn, P.A., Gurney, J.J. (1987) Metasomatic phenomena in garnet peridotite facies mantle xenoliths from the Matsoku kimberlite pipe, Lesotho. In: Mantle Metasomatism, Acad Press, Lond pp 145220

Lawless, P.J., Gurney, J.J., Dawson, J.B. (1979) Polymict peridotites from the Bultfontein and De Beers mines, Kimberley, S. Africa. In: Boyd FR and Meyer HOA (eds) The mantle sample., AGU Washington pp 145155

McKenzie D, O’Nions RK (1991) Partial melt distributions from inversion of rare earth element concentrations. J Pet 32: 1021-1091

Shimizu N, Kushiro I (1975) The partitioning of REE between garnet and liquid at high pressure: preliminary experiments. Geophys Res Letts 2: 413-416

Tainton, K.M. (1992) The petrogenesis of Group-2 kimberlites and lamproites from the Northern Cape Province, South Africa. Ph.D. Thesis, Cambridge University of Cambridge 